\title{
Adoption of Certified Seed and Its Effect on Technical Efficiency: Insights From Northern Kazakhstan
}

\author{
Muratbek Baglan $^{1,2}$, Xue Zhou ${ }^{1,2}$, Gershom Endelani Mwalupaso ${ }^{3} \&$ Geng Xianhui $^{1,2}$ \\ ${ }^{1}$ College of Economics and Management, Nanjing Agricultural University, Nanjing, PR China \\ ${ }^{2}$ China Center for Food Security Studies, Nanjing Agricultural University Nanjing, Nanjing, PR China \\ ${ }^{3}$ School of Natural Resources, Copperbelt University, Kitwe, Zambia \\ Correspondence: Geng Xianhui, College of Economics and Management, Nanjing Agricultural University, No. 1 \\ Weigang, Nanjing, 210095, PR China. E-mail: gengxh@njau.edu.cn
}

Received: December 21, 2019

Accepted: January 20, $2020 \quad$ Online Published: February 15, 2020

doi:10.5539/jas.v12n3p175

URL: https://doi.org/10.5539/jas.v12n3p175

\begin{abstract}
This research was partially funded by a research grant from the Jiangsu Social Science Fund Key Project, "Study on the establishment and improvement of the system mechanism and policy system of urban-rural integration and development in Jiangsu" (K0201900192) and a project funded by the Priority Academic Program Development of Jiangsu Higher Education Institutions (PAPD).
\end{abstract}

\begin{abstract}
Despite the economic and food security importance of the Kazakh wheat sector, current statistics suggest a yield gap between actual and potential yields. In view of this, farmers, stakeholders and the government are looking for agricultural technologies to increase the output. To this end, adoption of certified seeds is being promoted. The reasoning is that certified seed is produced from seed of known genetic origin and genetic purity, in a controlled and tested manner, processed and declared in accordance with the Law on Seeds and thus, could aid in producing maximum obtainable output. Unfortunately, little is known on whether this could affect wheat production and technical efficiency more than the conventional seed as such a subject has never benefitted from empirical analysis. To begin to fill this research gap, data from smallholder farms in Kazakhstan is used to evaluate the impact of adoption on technical efficiency by applying the stochastic production frontier. Results indicate that adoption of certified seed has productivity effects. Precisely, adopters are $20 \%$ more efficient than their counterparts. To a large extent, this is attributable to the quality of seeds used. Therefore, our study demonstrates the importance of certified seed adoption and accentuates the role governments can play in ensuring seed quality for enhanced technical efficiency.
\end{abstract}

Keywords: technical efficiency, stochastic frontier analysis, wheat, certified seed, Kazakhstan

\section{Introduction}

Agriculture is one of the prime movers of the national economy in most developing countries (Babu \& Pinstrup-Andersen, 2000; Baydildina et al., 2000). For instance, in Kazakhstan, the wheat industry contributes substantial economic and social benefits. As a matter of fact, wheat accounts for $80 \%$ of total cropping land, making Kazakhstan the third largest wheat grain producer and the second largest net exporter among the Balkan sea countries (Pomfret, 2014). Particularly, its involvement in wheat production and export potential makes the country unique among central Asian countries because wheat is a strategic crop for food security and livelihood improvement. Since wheat is a dominant crop, any change in production is more likely to affect the producers' welfare and national economy (Satybaldin, 1998). In view of this, the government and development partners have been emphasizing the need for increased adoption of modern agricultural technologies to enhance productivity (Adesina \& Zinnah, 1993; Admassie \& Ayele, 2004; Boothby, Dufour, \& Tang, 2010). In this regard, use of certified seeds is held as priority and prominent in their campaigns.

Different from other Asian countries, Kazakhstan seed system is strongly managed by the state under agricultural and research institute (FAO, 2013). The system has existed from 1992 and is quasi-monopolized with an inclusion of Scientific Research Institutes (SRI) which provides and inspects quality of certified seed. In addition, agricultural research institutes and universities are the sources for the pre-basic and basic seed. Kazakhstan seed 
sector is administered and controlled by legislation and rules that were approved by representative parliaments. Seed certification and quality control services are provided by the public sector throughout the region. The inspection of seed producers' fields with some decentralized laboratories, control of the quality of seed marketed and inspection of processing plants remains the responsibility of the state (Abou-Jawdah, Sobh, \& Saad, 2001; Auriol \& Schilizzi, 2003). All administrative regions and district level decentralized laboratories report directly to the Ministry of Agriculture. Also, all development stakeholders in the region are sensitized on the importance of improved seed in contributing to boost agricultural productivity and production. The principal seed policy has been to ensure a continuous and wide use of high quality seeds. Therefore, in an attempt to incite adoption of yield-increasing technologies, the government of Kazakhstan has been promoting and actively participating in certified seed validation.

The discouragement of uncertified seeds is motivated by the fact that: (i) prolonged use leads to a decline in fertility (Jørgensen, Hauser, \& Jørgensen, 2007); (ii) often infected with warehouse insects and diseases (Gaines, Preston, Byrne, Henry, \& Westra, 2007); (iii) contain more weeds, broken seeds, and empty shells and (Gaines et al., 2007; Jørgensen et al., 2007); (iv) can only be protected with lower quality pesticides (Gaines et al., 2007). However, up till now, there is limited proof to validate whether use of certified seeds improves technical efficiency (the ability to produce maximum obtainable output from a given set of inputs under an existing technology). Thus, to a great extent, the lack of empirical evidence may have obstructed the formulation of policies capable of simultaneously addressing the current volatility in wheat productivity and rural development (Brown \& Miller, 2008).

For the last two to three decades, a number of in-depth improved agricultural technology adoption studies have been conducted and agricultural transformation strategies were designed. Majority of the technological input studies focused on the promotion of improved crop varieties adoption to boost productivity and household income of rural poor farmers. Mathenge, Smale, and Olwande (2014), found that adoption of high yield variety of selected cereals (Maize, wheat and rice) impacts on household welfare and poverty reduction in Asia and Latin America. Langyintuo and Mungoma (2008) also add that to realize rural transformation and production enhancement, input technology change is a fundamental element. Thus, the assertion is that households who use ordinary seed have more challenge on food security and poverty than those who use improved seed. Likewise, Shiferaw, Kebede, Kassie, and Fisher (2015), support this logic and stated that, introducing new agricultural technology can benefit poor subsistence farmers and more educated farmers by providing basic information to enhance productivity. However, the major weakness of the aforementioned studies is the failure to state whether the improved seeds were certified and if so how the certification system was operated. Also, the methodological discrepancies of failing to account for biases from observed variables in estimating productivity effects.

Therefore, to bridge the research gap, this present study investigates whether farmers indeed adopt certified seed and the impact it has on technical efficiency. The results are very essential for policymakers because wheat is a staple food for most developing countries and as such measures that scale up the efficiency in production are pivotal for attaining zero hunger and poverty reduction. Particularly for Kazakhstan, since majority of the population live in rural area, increasing productivity to address food security is highly prioritized and considered as solution.

Consequently, the study contributes to the literature in two ways. First, we attempt to establish the adoption intensity of certified wheat seeds. This is very important because availability of agricultural innovations does not necessarily mean farmers are making use of it to leverage the benefits from espousal. Second, we employ a robust empirical strategy that addresses endogeneity, an element that leads to biased estimation which eventually makes policy formulation not cogent enough for the intended objectives. Given the need for agriculture to augment food production, ensuring that policy is informed using robust estimates is mandatory.

The remainder of the paper is structured as follows: Section 2 presents the materials and methods, Section 3 presents results and its concomitant discussion and Section 4 concludes and provides policy recommendations.

\section{Materials and Methods}

\subsection{Study Site}

The study was conducted in Kazakhstan's northern region (Akmola, Kostanay and North Kazakhstan) (Dara et al., 2018). The country has a population of $18,497,318$ and is the ninth largest country in the world $(2,717,300$ sq $\mathrm{km}$ ). Agriculture is one of the leading branches of the economy, and the share of the agricultural sector in the Gross Domestic Product (GDP) is approximately 5-6\%. More than $74 \%$ of the country's territory is suitable for agricultural production, but only $25 \%$ of the land is arable. The primary agricultural products are wheat, corn, rice, oats, cotton, potatoes, vegetables, sugar beets, and sunflowers. 
Interestingly, Kazakhstan is one of the major producers and exporters of wheat in the world (Pavlova, Varcheva, Bokusheva, \& Calanca, 2014).

The selected study area produces more than $80 \%$ of the wheat in the country (Figure 3 ). There are three prevalent groups of agricultural producers in the country, large agricultural enterprises, smaller individual farms mostly engaged in grain production, and tiny household economies focused on vegetables and livestock. Regarding wheat production, smallholder farmers dominate. The country has two planting seasons for wheat-spring and winter. The production is mostly rain fed, and the continental climatic condition has a range of annual precipitation from 150-400 $\mathrm{mm}$. Additionally, on the grounds that the wheat grain has been deemed to be of poor quality, several certified wheat varieties have been released by Red Fall Experimental Station since 2000, including Naz, Sapaly, Yubilieynaya 60, Akterekskaya, Almaly, Alia, Egemen, Nureke, Ramin, Karasay, Maira, Konditerskaya, Rassad, Mereke 70, Farabi, and Alatau (Abugalieva \& Peña-Bautista, 2010).

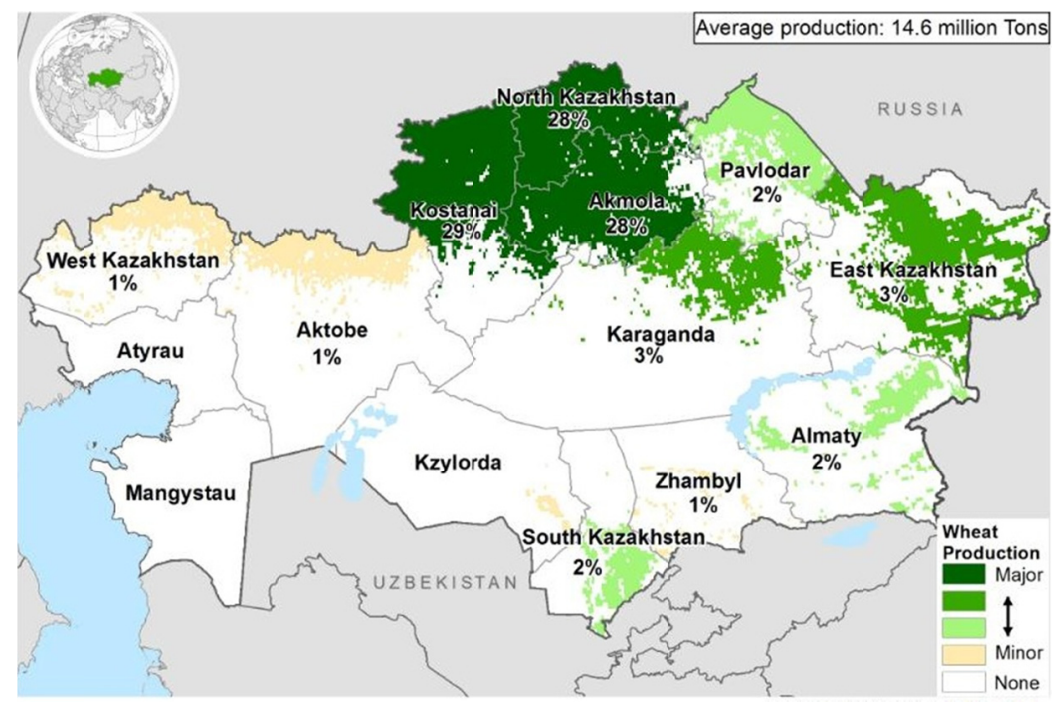

Figure 1. Wheat production in Kazakhstan by oblast

Source: State statistical agency of Kazakhstan.

\subsection{Data and Variable Description}

Cross-sectional data from a 2019 household survey (April-June) conducted in the northern part of Kazakhstan are used in this study. A multistage sampling procedure was employed to select the sample. First, three regions (Kostanai, Akmola and North Kazakhstan) with the same farming systems and agro-ecologies were purposefully nominated. This selection was based on the regional government, development of stakeholders' interventions, and strong certified seed campaign. The purposeful sampling technique allows the researcher to conveniently select the area of study on the basis of the potential respondents' knowledge of the subject under investigation and the availability of the practice (Saunders, 2011). Second, the quota-sampling technique was used to select 3 communities from each of the 3 regions. According to Saunders (2011), this sampling procedure permits researchers to limit the specific number that they select from a population. In the interest of having a proportional representation of members from different groups in a sample, quota sampling is the best approach (Owen, McNeill, \& Callum, 1998). Finally, twenty-five wheat farmers (225 in total, i.e., 3 regions $\times 3$ communities $\times 25$ wheat farmers) were randomly chosen using farmer lists obtained from the ministry of agriculture in the locality (Table 1). 
Table 1. Sample from each community in each region

\begin{tabular}{|c|c|c|c|c|c|}
\hline Region & Community & Sample & Total & Adopters & Non-adopters \\
\hline & Uzunkol & 25 & & & \\
\hline \multirow[t]{2}{*}{ Kostanay } & Fedorovka & 25 & 75 & 35 & 40 \\
\hline & Zarechnoe & 25 & & & \\
\hline & Petrovka & 25 & & & \\
\hline \multirow[t]{3}{*}{ North Kazakhstan } & Ruzayevka & 25 & 75 & 32 & 43 \\
\hline & Sovetskoye & 25 & & & \\
\hline & Akmol & 25 & & & \\
\hline \multirow[t]{2}{*}{ Akmola } & Kapitonovka & 25 & 75 & 25 & 50 \\
\hline & Urumkay & 25 & & & \\
\hline Total & & & 225 & 92 & 133 \\
\hline
\end{tabular}

Experienced and well-trained enumerators collected the data using a structured pretested questionnaire. This instrument was substantially rich in content because it included many variables related to the institutional center access, farming practices, farming inputs, actual production, and revenue from wheat sales. To comprehend the impact of certified seed adoption realistically and correctly, a question on the status of certified seed adoption was asked explicitly. Other demographic and socioeconomic data were also collected. The explanatory variables and factors in production disclose that there are significant differences in characteristics between adopters and non-adopters (Table 2).

Table 2. Variable description and summary statistics

\begin{tabular}{|c|c|c|c|c|}
\hline Category & Description & Pooled $(\mathrm{N}=225)$ & Users $(\mathrm{N}=92)$ & Non-users $(\mathrm{N}=133)$ \\
\hline \multicolumn{5}{|c|}{ Explanatory variables } \\
\hline Gender & Sex of household head $(1=$ male $)$ & $0.83(0.06)$ & $0.86(0.03)$ & $0.85(0.02)$ \\
\hline Experience & Farming experience of household head in years & $21.71(0.87)$ & $18.07(1.53)$ & $22.67(1.01)^{* *}$ \\
\hline Schooling & Household head's number of years of formal education & $11.24(0.25)$ & $11.62(0.28)$ & $8.35(0.26)^{* * *}$ \\
\hline Cooperative & Households who are members of a cooperative $(1=$ member $)$ & $0.79(0.06)$ & $0.79(0.01)$ & $0.97(0.07)^{* * *}$ \\
\hline Credit & Household's access to credit ( $1=$ has access $)$ & $0.52(0.04)$ & $0.69(0.07)$ & $0.48(0.04)^{* *}$ \\
\hline Extension & Household's access to extension services $(1=$ access $)$ & $0.53(0.03)$ & $0.98(0.02)$ & $0.42(0.04)^{* * *}$ \\
\hline Household size & Number of people in a household & $6.14(0.23)$ & $6.30(0.50)$ & $6.09(0.26)$ \\
\hline Farm size & Total land owned per capita & $3.62(0.09)$ & $3.15(0.17)$ & $3.74(0.10)^{* * *}$ \\
\hline Market & Distance from the house to the market in kilometers & $8.50(0.26)$ & $6.48(0.53)$ & $9.04(0.28)^{* * *}$ \\
\hline Income & Annual income from wheat sales (USD) & $210.33(1.20)$ & $200.54(1.55)$ & $170.20(1.80)^{* *}$ \\
\hline \multicolumn{5}{|l|}{ Classical inputs } \\
\hline Seed & Quantity of wheat seed used in kgs & $26.57(1.41)$ & $26.42(3.37)$ & $26.60(1.55)$ \\
\hline Land & Area cultivated for wheat production & $3.75(0.09)$ & $3.45(0.17)$ & $3.84(0.11)^{*}$ \\
\hline Fertilizer & Fertilizer quantity used (kgs) & $580.45(47.90)$ & $612.20(94.62)$ & $478.05(49.33)^{*}$ \\
\hline Labor & The hours of labor used in labor-days & $134.74(6.26)$ & $134.86(19.38)$ & $134.71(6.08)$ \\
\hline
\end{tabular}

Note. The figures in parentheses are the standard errors of the mean, while $*, * *$, and $* * *$ indicate the statistical significance levels at $10 \%, 5 \%$, and $1 \%$, respectively.

\subsection{Key Variable Measurement}

Certified seed adoption is the primary explanatory variable and is captured as a dummy variable. We consider a household as an adopter if they used at least one type of certified wheat seed during the survey year. Accordingly, 1 is for adopters and 0 is otherwise. This approach is consistent with that of many researchers who have studied seed adoption (Admassie \& Ayele, 2004; Shiferaw, Kassie, Jaleta, \& Yirga, 2014; Teklewold, Kassie, \& Shiferaw, 2013; Varma, 2018).

On the other hand, the technical efficiency level of each wheat farmer is a key output variable that is used to facilitate assessments of whether the adoption of certified seed is associated with improved efficiency. Thus, a stochastic frontier analysis is applied as explained in the empirical strategy section.

\subsection{Econometric Framework and Estimation Strategy}

A one-step stochastic frontier analysis (SFA) is applied to model the wheat farmers' productivity by employing the Cobb-Douglas production function on a matched sample (to address biases emanating from observed 
characteristics using propensity score matching-'1-1 nearest neighbor matching without replacement'). The SFA is a parametric approach formulated by Aigner, Lovell, and Schmidt (1977) on which efficiency measurements rest; it is generally specified is as follows:

$$
Y_{i}=f\left(x_{i}, \beta\right) \cdot \exp \left(v_{i}\right) \cdot \exp \left(-u_{i}\right)
$$

where, $Y_{i}$ is the output of the $\mathrm{i}$-th farmer, $x_{i}$ is a vector of the inputs, $\beta$ is a vector of parameters to be estimated, and $v_{i} \sim \mathrm{N}\left(0, \delta_{\mathrm{v}}^{2}\right)$ and $u_{i} \sim N^{+}\left[f(\mu, \alpha), \delta_{\mathrm{u}}^{2}\right]$ are the random error and the inefficiency term, respectively.

From Equation 1, Battese and Coelli (1995) indicate that the factors influencing technical efficiency can be estimated as follows:

Finally, TE is given by Equation 3,

$$
u_{i}=f\left(\mu_{i}, \alpha\right)
$$

$$
T E_{i}=\frac{y_{i}}{y_{i}^{*}}=\frac{f\left(x_{i}, \beta\right) \exp \left(v_{i}-u_{i}\right)}{f\left(x_{i}, \beta\right) \exp \left(v_{i}\right)}=\exp \left(-u_{i}\right)
$$

where, $y_{i}=f\left(x_{i}, \beta\right) \exp \left(v_{i}-u_{i}\right)$ is the observed production with inefficiency and $y_{i}^{*}=f\left(x_{i}, \beta\right) \exp \left(v_{i}\right)$ is the frontier output quantity with no inefficiency.

With the aid of several estimation tests and rational indicators relevant to the properties of the different production models (we shortlisted the translog and $\mathrm{CD}$ ), the best model for the given data can be selected. In our case, the general procedure used to select the best model consists of conducting a likelihood ratio (LR) test after running both models as recommended by Belotti, Daidone, Ilardi, and Atella (2013), and Kumbhakar, Wang, and Horncastle (2015). This procedure ensures that a correct statistical decision is expressed based on the likelihood of how many additional times the data are under one model than its counterpart and the accuracy of the specified distributional assumption in the inefficiency estimation. The LR test general form is given by:

$$
L R=-2\left\{\ln \left[L\left(H_{A}\right)\right]-\ln \left[L\left(H_{0}\right)\right]\right\}
$$

where, $L\left(H_{0}\right)$ and $L\left(H_{A}\right)$ are the values of the likelihood function under the null and alternative hypotheses, respectively.

The LR test is employed as a statistical test to compare the goodness of fit of two models. Based on the likelihood ratio, a null model is compared to an alternative model. Despite the translog function being a general form in most productivity analyses, the parameters of $\mathrm{CD}$ are appropriate and suitable in our case, as confirmed by the statistical insignificance $(0.741)$ of the LR test. The CD function and its respective inefficiency function are specified as follows:

$$
\begin{gathered}
\ln Y_{i}=\beta_{0}+\beta_{i} \sum_{\mathrm{i}=1}^{4} \ln X_{i}+v_{i}-u_{i} \\
u_{i}=\alpha_{0}+\alpha_{1} \text { Certseed }_{i}+\sum \alpha_{i} m_{i}+z_{i}
\end{gathered}
$$

where, $Y_{i}$ is the wheat output, $X_{i}$ is a vector of the four classical inputs (land, fertilizer, seeds, and labor), $\beta_{0}$, $\alpha_{0}, \alpha_{1}, \alpha_{i}$ and $\beta_{i}$ are parameters to be estimated, $m_{i}$ is a vector of other determinants of technical inefficiency other than certified seed adoption, $u_{i}$ is a non-negative inefficiency component that follows a truncated-normal distribution and $v_{i}$ is a random error following a normal distribution for the production function while $z_{i}$ is a random error for the inefficiency model.

\section{Empirical Results and Discussion}

\subsection{Intensity of Certified Seed Adoption}

Table 3 presents the adoption intensity of the adopters. The figures are conclusive in showing that certified seeds are being used by the wheat farmers (although not in high enough amounts) and that there are various varieties of certified wheat seed available. The data provided by the adopters during questionnaire pretesting revealed that they only use certified seed of certified genetic origin to attain full fruition, which is the goal of any producer (Turner, Ortmann, \& Lyne, 2000). In support, Iqbal, Khan, Ahmad, and Ahmad (2001) contends that the prevalence of certified seed adoption for any crop will definitely lead to increased production, especially when the current environment (climate change, loss of soil fertility and increased pest attack incidences) does not favor full-fledged production under normal circumstances. 
Table 3. Intensity of certified seed adoption

\begin{tabular}{lll}
\hline Certified wheat seed varieties & Number of Adopters & Percent \\
\hline Naz & 60 & 65.2 \\
Sapaly & 47 & 51.1 \\
Yubilieynaya 60 & 80 & 86.9 \\
Akterekskaya & 78 & 84.8 \\
Almaly & 55 & 59.8 \\
Alia & 30 & 32.6 \\
Egemen & 84 & 91.3 \\
Nureke & 62 & 67.4 \\
Ramin & 58 & 63.0 \\
Karasay & 49 & 53.3 \\
Maira & 70 & 76.1 \\
Konditerskaya & 51 & 55.4 \\
Rassad & 69 & 75.0 \\
Mereke 70 & 34 & 37.0 \\
Farabi & 44 & 47.8 \\
Alatau & 50 & 54.3 \\
\hline
\end{tabular}

\subsection{Technical Efficiency Effects}

Table 4 presents the results of the SFA from which the impact of certified seed adoption on technical efficiency can be comprehended. We find that adoption of certified seed positively and significantly influences technical efficiency. This implies that given a fixed set of agricultural inputs, adopters produce wheat output closer to the maximum obtainable output than their counterparts. This result is plausible considering that a seed certification process guaranteeing seed quality has been developed in Kazakhstan (Abou-Jawdah et al., 2001; Auriol \& Schilizzi, 2003). The process starts with establishing the seed crop varietal, crop nurture and testing by experts, and ends with harvesting, processing, quality control and labeling under the supervision of the Ministry of Agriculture. This is done in strict accordance and only producers formally listed in the seed register participate (Mangold \& Bonner, 2006). Also, while seed processing is done at registered processing facilities, quality testing is carried out at accredited laboratories and package labeling is issued by the organization approved by the Ministry of Agriculture. It is anticipated that such an undertaking would assist farmers to realize a healthy and bountiful crop because the processed seed is considerably higher than the conventional uncertified seed on account of uniformity of seed size and quality (Goletti \& Chabot, 2000; Meng, Longmire, \& Moldashev, 2000). According to Iqbal et al. (2001), certified seeds are not only of good quality (i.e., free from damage or immature seeds and diseases) but also high in germination and vigor as well as genetic purity (Bernard, Hellin, Nyikal, \& Mburu, 2010). Considering that farmers are truly adopting certified seeds as revealed in Table 3, the results obtained in the SFA estimation is validated.

Similarly, Bernard et al. (2010) hypothesize that adopters of certified seed are likely to achieve higher yields $(10-30 \%)$ than their counterparts because they are using higher quality seeds. The belief by adherents of certified seed adoption is that only seeds treated and processed at registered facilities meet the prerequisites of a productive crop, warranting a remarkable harvest. Therefore, certified seed adoption facilitates higher yields (Jang \& Olson, 2010) consistent with the postulation by Iqbal et al. (2001).

Other significant determinants of technical efficiency include the household size, gender, education attainment and access to credit. The household size is very important for wheat farmers because it is a source of labor. We find that larger families have low technical inefficiency. As the household size increases, there is a more equitable labor distribution in the given task, leading to greater concentration, which facilitates improved technical efficiency. Our finding is similar to that of Amos (2007) but differs from the result of Mwalupaso, Wang, Rahman, Alavo, and Tian (2019), who found that the household size negatively influences the technical efficiency.

Gender is significant in improving the technical efficiency (Overfield \& Fleming, 2001; Udry, Hoddinott, Alderman, \& Haddad, 1995). One possible explanation is that most household heads are males and thus their numbers in the sample is higher. Another explanation is that more males than females are engaged in wheat production in Kazakhstan. In many studies evaluating the determinants of technical efficiency, gender has been found as a significant factor. While females play a significant role in agricultural activities, some tasks such as 
plowing are not performed by women. For this reason, male-headed households are more efficient than female-headed households, consistent with the finding of Dadzie and Dasmani (2010) but contrasting with the result of Chirwa (2007).

Jaime and Salazar (2011) assert that education expedites learning, advances access to information, endorses forward-looking attitudes, and eases the adoption of new technologies. Other scholars (Binam, Gockowski, \& Nkamleu, 2008; Külekçi, 2010; Rahman, 2010; Solís, Bravo-Ureta, \& Quiroga, 2009) support this assertion, which could be the best explanation for the positive and significant impact of education on technical efficiency. Our finding is consistent with that of Hyuha, Bashaasha, Nkonya, and Kraybill (2007), who also indicated higher levels of education as a determinant of productivity.

Finally, for the significant determinants, access to credit allows farmers to acquire the required resources for success in farming. More specifically, it provides the finances required for the optimal growth of the crop and has the potential to lead to the maximum obtainable output. According to Pius Chinwuba and Odjuvwuederhie Emmanuel (2006), credit is an important source of financing that empowers farmers to procure agricultural inputs in a timely manner, and this credit increases the probability of obtaining the maximum output from the deployed inputs. In addition, since the availability of loans reduces capital constraints, it is anticipated that credit access could influence the technical efficiency. However, Feder, Lau, Lin, and Xiaopeng (1989) caution that, in most cases, this type of effect depends on the size of the available credit.

We also find that access to extension service is not significant for non-adopters but significant for adopters. This result suggests that the extension service or the approach used is not effective for achieving the desired objective. By default, households that frequently contact extension experts are expected to adopt new technology and have better access to information (Gelaw \& Bezabih, 2004), which leads to farm productivity as concluded by Mwalupaso et al. (2019).

Contrary to our expectation, the experience of the farmer is insignificant. Since the expected acquisition of dexterity leads to auspicious outcomes (Ritson, 1997), an insignificant result suggests that experience alone is not enough in this case. There could be some conditions that need to be met for this factor to be significant, and adoption of certified seed could be one of them. Some factors (diseases) are outside of farmer control regardless of their experience, and so this could best explain the lack of cogent impact on technical efficiency. Our finding is similar to that of Oladeebo and Fajuyigbe (2007) but differs from that of Gul, Koc, Dagistan, Akpinar, and Parlakay (2009), who found that farming experience has positive and significant impacts on technical efficiency.

Table 4. SFA estimation for conventional and sample-selection SPF

\begin{tabular}{llll}
\hline Variables & Pooled & Adopters & Non-adopters \\
\hline lnFertilizer & $0.126(0.179)$ & $0.055(0.058)$ & $0.073(0.136)$ \\
lnLand & $0.608(0.129)^{* * *}$ & $0.397(0.122)^{* * *}$ & $0.792(0.066)^{* * *}$ \\
lnLabor & $0.029(0.038)$ & $0.224(0.055)^{* * *}$ & $0.008(0.003)^{* *}$ \\
lnSeed & $0.257(0.062)^{* * *}$ & $0.693(0.099)^{* * *}$ & $0.220(0.044)^{* * *}$ \\
Constant & $6.703(0.588)^{* * *}$ & $7.278(0.501)^{* * *}$ & $6.630(0.367)^{* * *}$ \\
Technical Inefficiency Function & & & \\
CertSeed & $-0.294(0.099)^{* * *}$ & & $-1.430(1.671)^{* *}$ \\
Household size & $-0.040(0.011)^{* * *}$ & $-0.504(0.152)^{* *}$ & $-2.789(3.799)^{*}$ \\
Gender & $-0.052(0.047)^{*}$ & $-0.926(0.256)^{*}$ & $-0.270(0.308)$ \\
Experience & $-0.008(0.013)$ & $-0.048(0.074)$ & $-0.988(0.645)^{*}$ \\
Schooling & $-0.023(0.013)^{* *}$ & $-0.296(0.153)^{*}$ & $-0.557(0.275)^{*}$ \\
Credit & $-0.102(0.051)^{*}$ & $-0.834(0.414)^{* *}$ & $1.824(2.606)$ \\
Extension & $0.055(0.090)$ & $1.113(1.350)$ & $-18.982(24.985)$ \\
Constant & $0.372(0.171)^{* *}$ & $4.252(1.137)^{* * *}$ & \\
Model diagnostics & & & 51.089 \\
Log likelihood & 35.514 & 13.486 & 0.735 \\
Mean TE & 0.835 & 0.935 & 92 \\
N & 225 & 92 & \\
\hline
\end{tabular}

Note. Figures in parentheses are standard errors of the coefficient, while ${ }^{*},{ }^{*}$, and ${ }^{* * *}$ indicate statistical significance levels at $10 \%, 5 \%$, and $1 \%$, respectively. 
To understand the efficiency levels across groups to a satisfactory extent, Figure 2 presents the distribution. Compared to adopters, the majority of non-adopters have efficiency scores lower than 70 percent. As earlier stated, given that the government is involved in the registration and monitoring of registered seed certification outlets, an increased efficiency is expected.

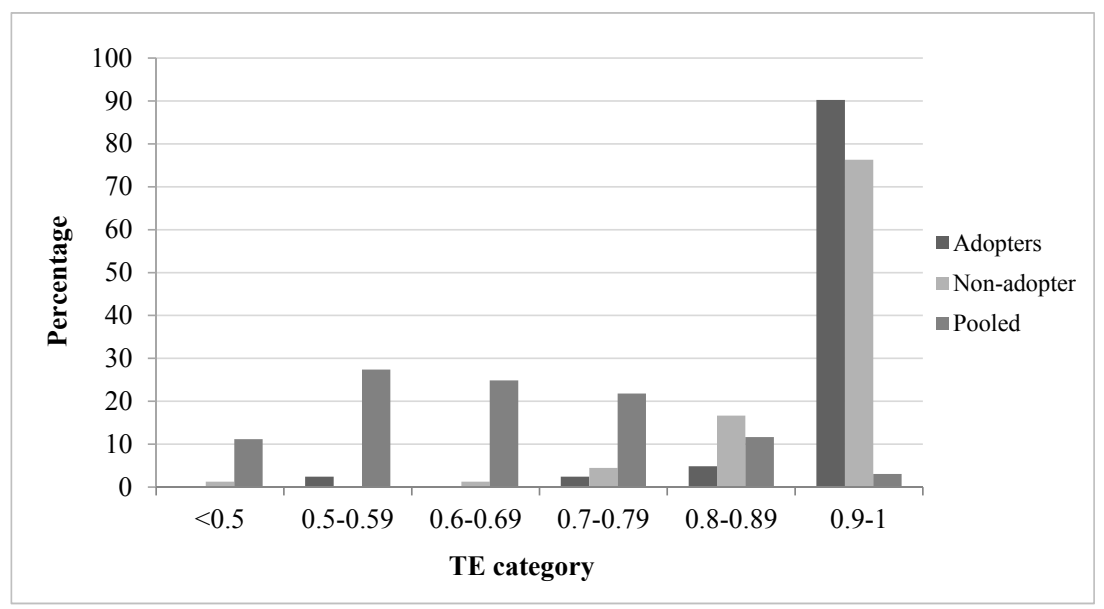

Figure 2. Technical efficiency distribution

\section{Conclusion and Policy Recommendation}

Seeds are the basic unit of plant propagation and as such they are the most pivotal agricultural input for increased agricultural productivity. In Kazakhstan, a leading producer of wheat, the government has been stimulating the adoption certified seeds in an attempt to augment farmers' technical efficiency. It is anticipated that such an undertaking would assist farmers to realize a healthy and bountiful crop because the processed seed is considerably higher than the conventional (uncertified) seed regarding uniformity of seed size and quality. However, there is limited evidence on the impact of certified seed espousal on technical efficiency. Therefore, the present study was undertaken to establish the adoption intensity and evaluate the technical efficiency effects.

The findings indicate that farmers are indeed adopting various available certified seed varieties and this has positively influenced their technical efficiency in wheat production. One distinct and cardinal element to this effect is the role of the state in actively participating in the seed certification process to ensure that the processing and distribution conforms to the seed laws. This suggests that there is authenticity in quality of the seeds considering that government is keen to achieve increased productivity in wheat production owing to the contribution it makes to the livelihoods of farmers and the national economy. Therefore, Kazakhstan provides a learning case for countries seeking to achieve improved technical efficiency on account of certified seeds.

Therefore, to make adoption of certified seed at a mind blogging scale, research, extension, input supply services, distribution and marketing are some of the major component recommended for an effective seed supply system. Also, quality, and timeliness of delivery, motivating and encouraging private sectors and community based seed multipliers could be considered as policy intervention.

\section{References}

Abou-Jawdah, Y., Sobh, H., \& Saad, A. (2001). Incidence of potato virus diseases and their significance for a seed certification program in Lebanon. Phytopathologia Mediterranea, 40(2), 113-118.

Abugalieva, A., \& Peña-Bautista, R. (2010). Grain quality of spring and winter wheat of Kazakhstan. Asian and Australasian Journal of Plant Science and Biotechnology, 4(1), 87-90.

Adesina, A. A., \& Zinnah, M. M. (1993). Technology characteristics, farmers' perceptions and adoption decisions: A Tobit model application in Sierra Leone. Agricultural Economics, 9(4), 297-311. https://doi.org/10.1016/0169-5150(93)90019-9

Admassie, A., \& Ayele, G. (2004). Adoption of Improved Technology in Ethiopia, Ethiopian Development Research Institute.

Aigner, D., Lovell, C. K., \& Schmidt, P. (1977). Formulation and estimation of stochastic frontier production function models. Journal of Econometrics, 6(1), 21-37. https://doi.org/10.1016/0304-4076(77)90052-5 
Amos, T. T. (2007). An analysis of productivity and technical efficiency of smallholder cocoa farmers in Nigeria. Journal of Social Sciences, 15(2), 127-133. https://doi.org/10.1080/09718923.2007.11892573

Auriol, E., \& Schilizzi, S. G. (2003). Quality signaling through certification. Theory and an application to agricultural seed markets (IDEI working paper 165). Institut d'Economie Industrielle (IDEI), Toulouse.

Babu, S., \& Pinstrup-Andersen, P. (2000). Achieving food security in Central Asia-Current challenges and policy research needs. Food Policy, 25(6), 629-635. https://doi.org/10.1016/S0306-9192(00)00031-2

Battese , G. E., \& Coelli, T. J. (1995). A model for technical inefficiency effects in a stochastic frontier production function for panel data. Empirical Economics, 20(2), 325-332. https://doi.org/10.1007/ BF01205442

Baydildina, A., Akshinbay, A., Bayetova, M., Mkrytichyan, L., Haliepesova, A., \& Ataev, D. (2000). Agricultural policy reforms and food security in Kazakhstan and Turkmenistan. Food Policy, 25(6), 733-747. https://doi.org/10.1016/S0306-9192(00)00035-X

Belotti, F., Daidone, S., Ilardi, G., \& Atella, V. (2013). Stochastic frontier analysis using Stata. The Stata Journal, 13(4), 719-758. https://doi.org/10.1177/1536867X1301300404

Bernard, M., Hellin, J., Nyikal, R. A., \& Mburu, J. G. (2010). Determinants for use of certified maize seed and the relative importance of transaction costs.

Binam, J. N., Gockowski, J., \& Nkamleu, G. B. (2008). Technical efficiency and productivity potential of cocoa farmers in West African countries. The Developing Economies, 46(3), 242-263. https://doi.org/10.1111/ j.1746-1049.2008.00065.x

Boothby, D., Dufour, A., \& Tang, J. (2010). Technology adoption, training and productivity performance. Research Policy, 39(5), 650-661. https://doi.org/10.1016/j.respol.2010.02.011

Brown, C., \& Miller, S. (2008). The impacts of local markets: A review of research on farmers markets and community supported agriculture (CSA). American Journal of Agricultural Economics, 90(5), 1298-1302. https://doi.org/10.1111/j.1467-8276.2008.01220.x

Chirwa, E. W. (2007). Sources of technical efficiency among smallholder maize farmers in Southern Malawi. Chancellor College, University of Malawi.

Dadzie, S. K., \& Dasmani, I. (2010). Gender difference and farm level efficiency: Metafrontier production function approach. Journal of Development and Agricultural Economics, 2(12), 441-451.

Dara, A., Baumann, M., Kuemmerle, T., Pflugmacher, D., Rabe, A., Griffiths, P., ... Hostert, P. (2018). Mapping the timing of cropland abandonment and recultivation in northern Kazakhstan using annual Landsat time series. Remote Sensing of Environment, 213, 49-60. https://doi.org/10.1016/j.rse.2018.05.005

Feder, G., Lau, L. J., Lin, J. Y., \& Xiaopeng, L. (1989). Agricultural credit and farm performance in China. Journal of Comparative Economics, 13(4), 508-526. https://doi.org/10.1016/0147-5967(89)90024-3

Gaines, T., Preston, C., Byrne, P., Henry, W. B., \& Westra, P. (2007). Adventitious presence of herbicide resistant wheat in certified and farm-saved seed lots. Crop Science, 47(2), 751-754. https://doi.org/10.2135/ cropsci2006.06.0368

Gelaw, F., \& Bezabih, E. (2004). Analysis of technical efficiency of wheat production: A study in Machakel Woreda, Ethiopia (M.Sc Thesis, Alemaya University).

Goletti, F., \& Chabot, P. (2000). Food policy research for improving the reform of agricultural input and output markets in Central Asia. Food Policy, 25(6), 661-679. https://doi.org/10.1016/S0306-9192(00)00036-1

Gul, M., Koc, B., Dagistan, E., Akpinar, M. G., \& Parlakay, O. (2009). Determination of technical efficiency in cotton growing farms in Turkey: A case study of Cukurova region. African Journal of Agricultural Research, 4(10), 944-949.

Hyuha, T., Bashaasha, B., Nkonya, E., \& Kraybill, D. (2007). Analysis of profit inefficiency in rice production in Eastern and Northern Uganda. African Crop Science Journal, 15(4).

Iqbal, M., Khan, M. A., Ahmad, M., \& Ahmad, B. (2001). Determinants of Higher Wheat Productivity in Irrigated Pakistan. The Pakistan Development Review, 753-766. https://doi.org/10.30541/v40i4IIpp.753-766

Jaime, M. M., \& Salazar, C. A. (2011). Participation in organizations, technical efficiency and territorial differences: A study of small wheat farmers in Chile. Chilean Journal of Agricultural Research, 71(1), 104. https://doi.org/10.4067/S0718-58392011000100013 
Jang, J., \& Olson, F. (2010). The role of product differentiation for contract choice in the agro-food sector. European Review of Agricultural Economics, 37(2), 251-273. https://doi.org/10.1093/erae/jbq013

Jørgensen, T., Hauser, T. P., \& Jørgensen, R. B. (2007). Adventitious presence of other varieties in oilseed rape (Brassica napus) from seed banks and certified seed. Seed Science Research, 17(2), 115-125. https://doi.org/10.1017/S0960258507708103

Koopmans, T. C. (1951). An analysis of production as an efficient combination of activities. Activity analysis of production and allocation (Cowles Commission Monograph No. 13, pp. 33-97). John Wiley \& Sons, Inc., New York, N. Y.; Chapman \& Hall, Ltd., London.

Külekçi, M. (2010). Technical efficiency analysis for oilseed sunflower farms: A case study in Erzurum, Turkey. Journal of the Science of Food and Agriculture, 90(9), 1508-1512. https://doi.org/10.1002/jsfa.3975

Kumbhakar, S. C., Wang, H.-J., \& Horncastle, A. P. (2015). A practitioner's guide to stochastic frontier analysis using Stata. Cambridge University Press, UK. https://doi.org/10.1017/CBO9781139342070

Langyintuo, A. S., \& Mungoma, C. (2008). The effect of household wealth on the adoption of improved maize varieties in Zambia. Food Policy, 33(6), 550-559. https://doi.org/10.1016/j.foodpol.2008.04.002

Mangold, R. D., \& Bonner, F. T. (2006). Certification of tree seeds and other woody plant materials. Woody Plant Seed Manual.

Mathenge, M. K., Smale, M., \& Olwande, J. (2014). The impacts of hybrid maize seed on the welfare of farming households in Kenya. Food Policy, 44, 262-271. https://doi.org/10.1016/j.foodpol.2013.09.013

Meng, E., Longmire, J., \& Moldashev, A. (2000). Kazakhstan's wheat system: Priorities, constraints, and future prospects. Food Policy, 25(6), 701-717. https://doi.org/10.1016/S0306-9192(00)00038-5

Mwalupaso, G. E., Wang, S., Rahman, S., Alavo, E. J.-P., \& Tian, X. (2019). Agricultural Informatization and Technical Efficiency in Maize Production in Zambia. Sustainability, 11(8), 2451. https://doi.org/10.3390/ su1 1082451

Oladeebo, J. O., \& Fajuyigbe, A. (2007). Technical efficiency of men and women upland rice farmers in Osun State, Nigeria. Journal of Human Ecology, 22(2), 93-100. https://doi.org/10.1080/09709274.2007.11906006

Overfield, D., \& Fleming, E. (2001). A note on the influence of gender relations on the technical efficiency of smallholder coffee production in Papua New Guinea. Journal of Agricultural Economics, 52(1), $153-156$. https://doi.org/10.1111/j.1477-9552.2001.tb00915.x

Owen, L., McNeill, A., \& Callum, C. (1998). Trends in smoking during pregnancy in England, 1992-7: Quota sampling surveys. $B M J, 317(7160), 728-730$. https://doi.org/10.1136/bmj.317.7160.728

Pavlova, V. N., Varcheva, S. E., Bokusheva, R., \& Calanca, P. (2014). Modelling the effects of climate variability on spring wheat productivity in the steppe zone of Russia and Kazakhstan. Ecological Modelling, 277, 57-67. https://doi.org/10.1016/j.ecolmodel.2014.01.014

Pius Chinwuba, I., \& Odjuvwuederhie Emmanuel, I. (2006). Determinants of yam production and economic efficiency among small-holder farmers in southeastern Nigeria. Journal of Central European Agriculture, $7(2), 337-342$.

Pomfret, R. (2014). The economies of central Asia (Vol. 318). Princeton University Press.

Rahman, S. (2010). Women's labour contribution to productivity and efficiency in agriculture: Empirical evidence from Bangladesh. Journal of Agricultural Economics, 61(2), 318-342. https://doi.org/10.1111/ j.1477-9552.2010.00243.x

Ritson, C. (1997). Marketing, agriculture and economics: Presidential address. Journal of Agricultural Economics, 48(1-3), 279-299. https://doi.org/10.1111/j.1477-9552.1997.tb01155.x

Satybaldin, A. (1998). Economic policy for grain production in Kazakstan. Paper presented at the Proceedings of the Kazakstan-CIMMYT Conference, 22-24 September 1997, Shortandy, Akmola, Kazakstan. https://doi.org/10.1016/S0301-4207(98)00036-1

Saunders, M. N. (2011). Research methods for business students (5th ed.). Pearson Education India.

Shiferaw, B., Kassie, M., Jaleta, M., \& Yirga, C. (2014). Adoption of improved wheat varieties and impacts on household food security in Ethiopia. Food Policy, 44, 272-284. https://doi.org/10.1016/j.foodpol.2013. 09.012 
Shiferaw, B., Kebede, T., Kassie, M., \& Fisher, M. (2015). Market imperfections, access to information and technology adoption in Uganda: Challenges of overcoming multiple constraints. Agricultural Economics, 46(4), 475-488. https://doi.org/10.1111/agec.12175

Solís, D., Bravo-Ureta, B. E., \& Quiroga, R. E. (2009). Technical efficiency among peasant farmers participating in natural resource management programmes in Central America. Journal of Agricultural Economics, 60(1), 202-219. https://doi.org/10.1111/j.1477-9552.2008.00173.x

Teklewold, H., Kassie, M., \& Shiferaw, B. (2013). Adoption of multiple sustainable agricultural practices in rural Ethiopia. Journal of Agricultural Economics, 64(3), 597-623. https://doi.org/10.1111/1477-9552. 12011

Turner, C. R., Ortmann, G. F., \& Lyne, M. C. (2000). Adoption of ISO 9000 quality assurance standards by South African agribusiness firms. Agribusiness: An International Journal, 16(3), 295-307. https://doi.org/ 10.1002/1520-6297(200022)16:3\%3C295::AID-AGR3\%3E3.0.CO;2-P

Udry, C., Hoddinott, J., Alderman, H., \& Haddad, L. (1995). Gender differentials in farm productivity: implications for household efficiency and agricultural policy. Food Policy, 20(5), 407-423. https://doi.org/ 10.1016/0306-9192(95)00035-D

Varma, P. (2018). Adoption of system of rice intensification under information constraints: An analysis for India. The Journal of Development Studies, 54(10), 1838-1857. https://doi.org/10.1080/00220388.2017.1336541

\section{Copyrights}

Copyright for this article is retained by the author(s), with first publication rights granted to the journal.

This is an open-access article distributed under the terms and conditions of the Creative Commons Attribution license (http://creativecommons.org/licenses/by/4.0/). 